\title{
кУЛЬТУРОЛОГИя
}

УДК 008.009

\section{М. Гайдошова}

\section{ПЕРВЫЕ ЖЕНЩИНЫ В АДВОКАТУРЕ СЛОВАКИИ: КУЛЬТУРОЛОГИЧЕСКИЙ АНАЛИЗ}

Статья рассказывает об истории адвокатуры в Словакии - о первых женщинах в адвокатуре и юридическом образовании и юридической практике, главным образом адвокатуре, после формирования Чехословацкой Республики (1918). Речь идет о первых женщинах-юристах за рубежом и в юридическом образовании на юридическом факультете Университета имени Коменского в Братиславе после 1921 г. Особое внимание уделяется женщинам в адвокатуре в Словакии в период 1918-1939 гг. В 1925 г. первая женщина была внесена в Словакии в реестр кандидатов адвокатуры, а в 1931 г. - в реестр адвокатов. До 1939 г. в Словакии было 86 женщин - кандидатов адвокатуры, и 14 из них стали адвокатами. В центре внимания автора статьи находится новый социальный феномен - женщина в адвокатуре. Библиогр. 13 назв.

Ключевые слова: женщина, адвокатура, адвокат, кандидат адвокатуры, юридическое образование, Словакия, первая половина XX в.

Gajdošová M. (Gajdoshova M.)

\section{THE FIRST WOMEN IN THE SLOVAKIAN LEGAL PROFESSION: A CULTURAL ANALYSIS}

The article represents a contribution to the history of Slovakian law: the entrance of women into the legal profession, legal education and legal practice, mostly advocacy in Slovakia - after the creation of Czechoslovak republic in 1918. A special part of this article is dedicated to women first in comparison with other countries and with the first women lawyers, and then it analyzes the first women students of law in Slovakia at the Law Faculty of Comenius University in Bratislava from 1921. The core part of the article is focused on women in advocacy in Slovakia (1918-1939). The first woman advocate candidate in Slovakia was inscribed into the list of advocates in 1925, first woman advocate in 1931. Until 1939 in Slovakia there were 86 women - advocacy candidates and 14 of them bacame advocates. This article traces a new social phenomenon: women in the legal profession. Refs 13.

Keywords: woman, advocacy, advocate, legal profession, legal education, Slovakia in first half of the $20^{\text {th }}$ century.

Адвокатура долгое время оставалась исключительно мужской сферой деятельности, таких понятий, как женщина-адвокат или леди-адвокат, просто не существовало. В Словакии появление женщин в адвокатуре стало реальностью

Гайдошова Мартина - PhD, старший преподаватель, Трнавский университет, Словацкая Республика, 91843, Трнава, Горнопоточна, 23; martina.gajdosova@truni.sk

Gajdoshova Martina - PhD, Assistant Professor, Trnava University, 23, Hornopotočná, 91843, Trnava, Slovak Republic; martina.gajdosova@truni.sk

(C) Санкт-Петербургский государственный университет, 2016 
после распада Австро-Венгрии и формирования Чехословацкой Республики (1918). В 1926 г. первые женщины Словакии получили дипломы докторов юридических наук, в 1925 г. женщина была впервые записана в реестр кандидатов на должность адвоката, а в 1931 г. - впервые внесена в реестр адвокатов. В настоящее время в адвокатуре Словакии примерно одинаковое число мужчин и женщин. Доступ в адвокатуру был открыт женщинам благодаря достижению ими равноправия. Появление женщин в адвокатуре стало возможным после того, как они получили право получать юридическое образование в университете: наличие диплома о высшем образовании было необходимым условием для регистрации в качестве адвоката. В то время когда в Словакии женщины только начинали обучаться на юридических факультетах, за рубежом уже практиковали выпускницы-юристы. Сегодня мы не можем точно сказать, как относились адвокаты к своим первым коллегам-женщинам. Вероятно, в определенный период решение женщины вступить в адвокатуру означало для нее сделать жизненный выбор между семьей и профессией: совместить и то, и другое не представлялось возможным. Еще в 1929 г. в решении коллегии адвокатов читаем: «Женщина-адвокат при вступлении в брак будет заниматься семейными делами и обязанностями, и это значит, что она не сможет отдать себя адвокатуре. <...> молодая женщина - кандидат на должность адвоката или хочет быть добросовестной матерью и хозяйкой, или хочет добросовестно подготовиться к адвокатской деятельности. В настоящее время у нее есть возможность свободно сделать выбор. Наша обязанность, как людей, обладающих жизненным опытом, честно признать, что совмещение одного с другим исключено» ${ }^{1}$. С тех пор положение изменилось: женщины-адвокаты, замужние и незамужние, стали частью интеллектуальной элиты, внесли вклад в развитие традиций адвокатуры.

\section{Первые женщины изучают право}

Женский вопрос был актуальной темой на рубеже XIX-XX вв. Женская тема звучала везде, к ней обращались и многие писатели, например Ф. М.Достоевский (студентка Виргинская в романе «Бесы»), В.С. Соловьев («Женский вопрос»). Новое время дало женщинам возможность получать различные профессии: становиться учителями, писателями, редакторами, переводчиками, врачами и юристами. Эмансипация была повсеместной. Образование в университете прежде было практически недоступно для женщин, потом студентки стали привычным явлением. Экономическая и социальная среда менялась, и получение женщинами высшего образования стало неотъемлемым элементом жизни. Женщины, окончившие университеты, присоединились к экономически активной части общества.

Женщины, выступавшие с речами в суде, известны уже во времена Древнего Рима: сохранились упоминания, в частности, о Карфании ${ }^{2}$. В Новое время особый интерес представляет период конца XIX - начала XX в. - время активного вступления женщин в мир права и адвокатуры. В Европе двери для женщин од-

\footnotetext{
${ }^{1}$ Решение адвокатской палаты Турчиянски Святый Мартин н. 85/1928/III/6 z 7.12.1929, доктор Блажена Зайицова (dr. Blažena Zajícová) [1].

${ }^{2}$ B Древнем Риме эдикт (1 $\$ 5$ D. III, 1 De postulando) запрещал женщинам выступать в качестве защитников на форуме. Причиной запрета стала Карфания - женщина, которая выступала с речами и мешала суду (см.: [2; 3]).
} 
ним из первых открыл Цюрихский университет студентки появились там в 1864 г., но доступ к юридическому образованию они получили позже. В 1890 г. из 70 студенток Цюрихского университета 4 изучали право [4, с.250]. В кантоне Цюрих первая женщина-адвокат появилась в 1898 г. Во Франции женщины могли изучать право с 1870 г., первой женщиной-адвокатом в 1900 г. стала Жанна Шовен (Jeanne Chauvin) [5, c. 87]. В Великобритании высшее образование для женщин стало доступным в 70-х годах XIX в., а первой женщиной-адвокатом здесь стала Ива Вильямс (Iva Williams) в 1922 г. В Польше первая женщина была записана в реестр адвокатов адвокатской палаты в 1925 г. в Варшаве, это была Елена Виевиорска (Helena Wiewiórska; урожденная Кононов-Кононович (Kononow-Kononowicz), 1888-1967), получившая юридическое образование в Санкт-Петербурге [4, с. 250]. В 1922 г. Мария Отто стала первой женщиной адвокатом в Германии, в 1928 г. - Марияна Бет, урожденная Вон Вайсл, в Австрии [6, S.34].

В России в дореволюционный период женщин в адвокатуре не было. Известность в этой сфере получила Екатерина Абрамовна Флейшиц (1888-1968). В 1907 г. она с отличием окончила юридический факультет Сорбонны, в 1909 г. сдала экстерном экзамены за курс юридического факультета в Петербургском университете, получив диплом первой степени. В том же году она была принята помощником присяжного поверенного округа Петербургской судебной палаты. Ей удалось стать первой в России женщиной-адвокатом, но только на короткое время. Эта исключительная женщина позже прославилась педагогическим, теоретическим делом и публикацией статей.

Однако присутствие женщин на юридическом факультете уже было составной частью университетской среды. Свидетельство этого мы находим, например, в романе Алексея Толстого «Хождение по мукам»: «В прошлом году Даша приехала из Самары в Петербург на юридические курсы (ей было 18 лет. - М.Г.) и поселилась у старшей сестры Екатерины Дмитриевны Соковниковой. Муж ее был адвокат, довольно известный; жили они шумно и широко» [8].

В США женщины получили доступ к юридическому образованию и возможность вести собственную юридическую практику немного раньше. В 1897 г. в США насчитывалось уже 275 женщин-адвокатов [9; 3].

\section{Первые женщины-юристы в Чехословакии}

В Австро-Венгерской империи женщины появились на юридическом факультете Карлова университета в Праге в начале XX в., но пока только в качестве вольнослушательниц, стать полноправными студентками они смогли только после возникновения Чехословацкой Республики в 1918 г. [10, с. 586]. Первой выпускницей юридического факультета стала в 1922 г. Андела Козакова, которая сначала работала в Министерстве социального обеспечения, а с 1929 г. - помощником нотариуса. Первой женщиной-адвокатом в Чехии и во всей Чехословакии была Матылда Моцова-Вихова (1929) [5, с. 87].

\footnotetext{
${ }^{3}$ Cм.: [3; 7].
} 


\section{Юридическое образование и женщины в Словакии во время Чехословацкой Республики (1918-1938/39)}

С возникновением Чехословацкой Республики появилась необходимость в собственных словацких юристах. В 1919 г. был основан Университет имени Коменского в Братиславе, а в 1921 г. в университете появился юридический факультет, обучение на котором началось 24 октября.

Изучение права на юридическом факультете в Братиславе происходило так же, как и в других университетах Чехословакии (Карлов университет в Праге, Университет Масарика в Брне и немецкий Университет Карла-Фердинанда в Праге). Структура и содержание обучения были основаны на австрийской системе, обучение занимало не менее восьми семестров. С самого открытия юридического факультета Университета имени Коменского на него принимали студентов обоих полов [1]. На зимний семестр 1921/22 г. было записано 199 студентов, в том числе 6 женщин. В довоенный период (до 1938/39 г.) на юридическом факультете в Братиславе обучались всего 312 женщин (каждая проучилась как минимум один семестр). Женщины составляли сначала около $2 \%$ от общего числа студентов, постепенно их число увеличилось до $8 \%$, позже составляло около $5 \%$. О социальном происхождении этих женщин можно узнать из метрических списков факультета, где содержатся данные об их отцах. В 1921/22-1938/39 г. $12 \%$ женщин - студенток юридического факультета были дочерьми адвокатов, нотариусов и судей. Если учитывать и другие должности в государственном управлении и администрации, то окажется, что женщин, происходящих из семей, имеющих отношение к юриспруденции, еще больше. То есть на юридическом факультете в Братиславе обучалось большое число студенток, чьи отцы также, скорее всего, имели высшее юридическое образование.

\section{Первые женщины в словацкой адвокатуре}

Первой женщиной, зарегистрированной в реестре кандидатов адвокатуры адвокатской палаты Турчански Святого Мартина, была Луиза Паппова. Это случилось 29 октября 1925 г. Всего в Словакии в тот момент насчитывалось 253 кандидата адвокатуры и 982 адвоката. Луиза Паппова еще до акта вручения диплома работала в адвокатской канцелярии доктора Милана Иванка, адвоката в Братиславе. Дочь Милана Иванка Надежда Иванкова позже также решила изучить право и стала кандидатом адвокатуры (как и ее супруг доктор Зденко Градски). Второй работодатель Луизы Папповой, доктор Гласер, также принажлежал к числу адвокатов, не видевших ничего необычного в образованной женщине: его супруга Мила Гласерова была доктором философии и даже два семестра изучала право вместе со своим сыном Павлом Гласером на юридическом факультете в Братиславе. В 1939 г. в реестре адвокатов Словакии было зарегистрировано уже 14 женщин. Единственной женщиной-адвокатом на Подкарпатской Руси в 1934 г. была доктор Леона Функова (в замужестве Ваисгаусова), практиковавшая в Ужгороде.

Первой студенткой юридического факультета в Словакии была, по всей видимости, Алжбета Циглерова, она же стала вторым (после Луизы Парровой) кандидатом адвокатуры, но прежде всего о ней следует упомянуть как о первой женщине, внесенной в реестр адвокатов в городе Кошице (1931). Уже будучи практикующим 
адвокатом, она вышла замуж, ее супруг, доктор Эрнест Вилдманн, работал у нее как кандидат адвокатуры. После пятилетней практики у своей жены Вилдманн был в 1936 г. зарегистрирован в реестре адвокатов. Далее они работали вместе в городе Кошице. В результате Венского арбитража город Кошице отошел Венгрии. Доктор Алжбета Циглирова, которая не принесла адвокатскую присягу новому Словацкому государству, была исключена из реестра адвокатов 2 ноября 1938 г. Она и ее муж погибли в лагере в 1944 г. [12, с. 125-127].

Общая профессия способствует сближению. Профессия может передаваться в семье - от родителей к детям, может сближать коллег - до такой степени, что деловые отношения переходят в семейные. Примеры тому можно найти в разные периоды истории. В жизни многих женщин-адвокатов важную роль играли семейные связи - эти женщины часто были родственниками, дочерьми юристов или становились женами адвокатов. Многие женщины-кандидаты так не стали адвокатами, потому что выбрали другую область юридической практики, о многих мы просто не имеем сведений. В некоторых случаях можно сделать вывод, что вступление в брак и появление собственной семьи означали для женщины уход из адвокатуры.

1938-1939 г. - период упадка в словацкой адвокатуре, затронувшего и женщин. В связи с чрезвычайными отношениями были наложены ограничения на вступление в адвокатуру и на смену места деятельности (предписание правительства № 219/1938 Сб. «О временных ограничениях в предпринимательстве»). После Венского арбитража и Мюнхенского договора многие адвокаты и кандидаты, которые остались работать на территории, отошедшей другому государству (например, Венгрии), были исключены из реестра. Причиной исключения могли быть и невыполнение предписания о месте деятельности адвоката на территории Словацкого государства (предписание правительства № 33/1939, Сл. зак.), и расовая дискриминация (предписание правительства № 63/1939 Сл. зак. «Об ограничении числа евреев в некоторых профессиях»): число евреев среди адвокатов и кандидатов не должно было превышать $4 \%$ от общего числа зарегистрированных в адвокатской палате. Нельзя не упомянуть о том, что много мужчин и женщин из числа адвокатов в годы войны были депортированы и погибли в лагерях смерти.

\section{Заключение}

С 1925 г. в Словакии постепенно росло число женщин - кандидатов в адвокаты, причем больше всего их было в 1936 г. (53), в 1939 г. было зарегистрировано только 19 женщин. С 1925 г. доля женщин-юристов увеличивалась, в 1938 г. их было уже 14,6 \% (44 из 302 кандидатов). До 1939 г. в Словакии было 86 женщин - кандидатов адвокатуры, к 1939 г. 14 из них стали адвокатами. Женщин среди адвокатов было немного, первая женщина была зарегистрирована в качестве адвоката в 1931 г. (это был 0,01\% от общего числа адвокатов - 1067). В 1938 г. мы видим наибольший процент женщин в адвокатуре Словакии довоенного периода $-1,2$ \%, 12 женщин из 1042 адвокатов. Но изменение политической обстановки и ограничения, наложенные на адвокатскую деятельность, послужили причиной того, что в 1939 г. в Словакии была зарегистрирована опять только одна женщина-адвокат доктор Мария Стара. 
Сегодня совсем другая ситуация. Словацкая адвокатская палата в феврале 2015 г. зарегистрировала почти 41 \% женщин (общее число адвокатов в Словакии составляет около шести тысяч), а среди кандидатов в адвокаты, число которых составляет сегодня около 2300, женщины занимают почти 56 \% [13].

\section{Литература}

1. Метрические книги и дела женщин Словацкой адвокатской палаты (1918-1939 гг.). Братислава.

2. Kerecman P., Maník R. História advokácie na Slovensku. Bratislava: Eurokódex, 2011. $655 \mathrm{~s}$.

3. Флейшии Е. А. О женской адвокатуре // Право, еженедельная юридическая газета. 1910. № 2. 10 янв.

4. Redzik A., Kotliński T.J. Historia adwokatury. Waszawa: Naczelna Rada Adwokacka, 2012. $400 \mathrm{~s}$.

5. Král V. Ženy v advokacii // Bulletin advokacie. 2013. N 1.

6. Advokaten 1938: Das Schicksal der in den Jahren 1938 bis 1945 verfolgten österreichischen Rechtsanwältinnen und Rechtsanwälte. Barbara Sauer / Ilse Reiter-Zatloukal. Wien: Manz Crossmedia, 2010. 386 S.

7. Екатерина Флейшиц - первая леди-адвокат // Судебно-юридическая газета. № 32. 2010. 23 апреля. URL: http://sud.ua/newspaper/2010/04/23/35976-ekaterina-flejshits-pervaya-ledi-advokat/ print (дата обращения: 17.03.2014).

8. Толстой А. Хождение по мукам. М.: Художественная литература, 1972.848 c.

9. Kozáková A. 1923: Ženy a právnické povolání // Všehrd. URL: http://casopis.vsehrd.cz/2013/12/1923zeny-a-pravnicke-povolani/ (accessed 01.11.2015).

10. Zavacká K. Právničky v Československej republike, Absolventky práva a právna prax v Československej republike po roku 1918 // Dudeková G. A., kol. Na ceste k modernej žene, kapitoly z dejín rodových vztahov na Slovensku. Bratislava: VEDA, 2011. S. 586-598.

11. Метрические книги и дела студентов (1921-1939) // Архив Университета имени Коменского в Братиславе. Фонд: Юридический факультет.

12. Sulaček J. Právnici práva zbavení. 1. časti. Bratislava: Slovenské národné múzeum - Múzeum židovskej kultúry, 2014. $151 \mathrm{~s}$.

13. Gajdošová M., Kerecman P. Prvé ženy v slovenskej advokácii. Bratislava: VEDA, 2015. 320 s.

Для цитирования: Гайдошова Мартина. Первые женщины в адвокатуре Словакии: культурологический анализ // Вестн. С.-Петерб. ун-та. Сер. 17. Философия. Конфликтология. Культурология. Религиоведение. 2016. Вып. 3. С. 83-89. DOI: 10.21638/11701/spbu17.2016.310

\section{References}

1. Metricheskie knigi i dela zhenshchin Slovatskoi advokatskoi palaty (1918-1939 g.) [Registry and acts of women of Slovak bar association (1918-1939)]. Bratislava.

2. Kerecman P., Maník R. História advokácie na Slovensku [History of Advocacy on Slovakia]. Bratislava, Eurokódex Publ., 2011. 655 p.

3. Fleishits E.A. O zhenskoi advokature [Woman's Advocacy]. Pravo, ezhenedel'naia iuridicheskaia gazeta [Law, Law-journal]. St. Petersburg, 1910, no. 2, 10.01.1910. (In Russian)

4. Redzik A., Kotliński T. J. Historia adwokatury. Waszawa, Naczelna Rada Adwokacka, 2012. $400 \mathrm{~s}$.

5. Král V. Ženy v advokacii [Women in the Advocacy]. Bulletin advokacie [Bulletin of advocacy]. Prague, 2013, no. 1,87 p.

6. Advokaten 1938: Das Schicksal der in den Jahren 1938 bis 1945 verfolgten österreichischen Rechtsanwältinnen und Rechtsanwälte. Barbara Sauer. Ilse Reiter-Zatloukal. Wien, Manz Crossmedia, 2010. $386 \mathrm{~S}$.

7. Ekaterina Fleishits - pervaia ledi-advokat [Catherine Fleyshits - first lady-lawyer]. Sudebnoiuridicheskaia gazeta. № 32. 23 aprelia 2010 [Judicial and legal newspaper. $N$ 32. April 23. 2010]. Available at: http://sud.ua/newspaper/2010/04/23/35976-ekaterina-flejshits-pervaya-ledi-advokat/print (accessed 17.3.2014).

8. Tolstoy A. Krížová cesta. Vydavatelstvo Slovenský spisovatel, Bratislava, 1960, c.15 (Russ. ed.: Tolstoi A. Khozhdenie po mukam. Moscow, Khudozhestvennaia literature Publ., 1972. 848 p.).

9. Kozáková A. 1923: Ženy a právnické povolání [1923: Women and the lawyer professions]. Všehrd. Available at: http://casopis.vsehrd.cz/2013/12/1923-zeny-a-pravnicke-povolani/ (accessed 01.11.2015). 
10. Zavacká K. Právničky v Československej republike, Absolventky práva a právna prax v Československej republike po roku 1918 [Women - Lawyers in the Czechoslovak Republic, graduates and law practice in the Czechoslovak Republic after 1918]. Dudeková G. A., kol.: Na ceste k modernej žene, kapitoly z dejín rodových vztahov na Slovensku [Dudeková, G. and coll.: On the way to the modern woman, Chapters of history of gender relationship in Slovakia]. Bratislava, VEDA, Publishing of Slovak Academy of Science, 2011, pp. 586-598.

11. Metricheskie knigi i dela studentov (1921-1939) [Registry and acts of students (1921-1939)]. Arkhiv universiteta imeni Komenskogo v Bratislave [Archive of Comenius University Bratislava]. Fond: Faculty of Law.

12. Sulaček J. Právnici práva zbavení. 1. čast' [Lawyers divested of law; 1. part]. Bratislava, Slovak National Museum - Museum of Jewish culture, 2014. 151 p.

13. Gajdošová M., Kerecman P. Prvé ženy v slovenskej advokácii [First women in Slovak advocacy]. Bratislava, VEDA, Publishing of Slovak Academy of Science, 2015. 320 p.

For citation: Gajdoshova M. The first women in the Slovakian legal profession: a cultural analysis. Vestnik of Saint Petersburg University. Ser. 17. Philosophy. Conflict studies. Cultury studies. Religious studies, 2016, issue 3, pp. 83-89. DOI: 10.21638/11701/spbu17.2016.310

Статья поступила в редакцию 15 ноября 2015 г. 